\title{
Clostridioides (Clostridium) difficile-associated diarrhea in equine in Minas Gerais, Brazil: clinical and microbiological characterization of six cases
}

\author{
Amanda Nádia Diniz' ${ }^{1}$ Diogo Soares Gonçalves Cruz ${ }^{1}$ (D) Carolina Pantuzza Ramos ${ }^{1}$ (D) \\ Carlos Augusto Oliveira Júnior ${ }^{1}$ (i) Isabella Caixeta Winter ${ }^{1}$ Jorge Tibúrcio Barbosa de Lima JiD $^{1}$ \\ Armando de Mattos Carvalho ${ }^{1}$ (D) Francisco Carlos Faria Lobato ${ }^{1}$ (D) Rodrigo Otávio Silveira Silva ${ }^{1^{*}}$ (D)
}

${ }^{1}$ Escola Veterinária, Universidade Federal de Minas Gerais (UFMG), 31270-901, Belo Horizonte, MG, Brasil. E-mail: rodrigo.otaviosilva@gmail.com. ${ }^{*}$ Corresponding author.

ABSTRACT: Clostridioides (Clostridium) difficile is the main causative agent of antimicrobial-related diarrhea in humans and a major pathogen-associated enteric disorder in foals and adult horses. Moreover, studies have suggested that animals are a possible reservoir of toxigenic C. difficile strains for humans. Despite this known importance, the epidemiology of C. difficile infection (CDI) in equine is still largely unknown. Therefore, this study described six cases of equine CDI occurring in Minas Gerais, Brazil, including the characterization of the isolates. All but one equine included in this research developed CDI after antimicrobial therapy, three of which occurred during hospitalization. Coinfection with Salmonella Heidelberg and S. Infantis was detected in three cases, making the antimicrobial treatment challenging. All animals recovered after metronidazole administration. All C. difficile isolates were susceptible to metronidazole and vancomycin, while three were resistant to moxifloxacin and two were resistant to clindamycin. The isolates were classified as $R T 126(n=4)$, $R T 078(n=1)$, and RT014/020 $(n=1)$, all previously reported infecting humans and animals worldwide.

Key words: foals, horses, nosocomial, zoonosis, colitis.

Diarreia por Clostridioides (Clostridium) difficile em equinos em Minas Gerais, Brasil: caracterização clínica e microbiológica de seis casos

RESUMO: Clostridioides (Clostridium) difficile é o principal agente envolvido em diarreias associadas ao uso de antimicrobianos em seres humanos e um enteropatógeno de grande relevância em quadros de diarreia em potros e equinos adultos. Em adição, estudos tem sugerido que animais são possíveis reservatórios de estirpes toxigênicas de C. difficile para humanos. Apesar da importância na saúde animal e humana, a epidemiologia da infecção por C. difficile (ICD) é ainda pouco conhecida. Dessa forma, o presente estudo tem como objetivo caracterizar seis casos de diarreia por C. difficile ocorridos em Minas Gerais, Brasil. Com exceção de um animal, todos os equinos incluídos no presente estudo desenvolveram ICD após antibioticoterapia, três dos quais durante a hospitalização. Coinfecção por Salmonella Heidelberg e S. Infantis foi detectada em três casos, tornando o tratamento antimicrobiano desafiador. Todos os animais recuperaram após administração de metronidazol. Os isolados obtidos no presente estudo foram sensiveis a metronidazol e vancomicina, porém três estirpes foram resistentes a moxifloxacina e duas a clindamicina. Os isolados foram classificados como ribotipos $126(n=4), 078(n=1)$ e $014 / 020(n=1)$, todos previamente relatados em seres humanos com ICD no Brasil e em outros países.

Palavras-chave: potros, cavalos, nosocomial, zoonose, colite.

\section{NOTE}

Clostridioides (Clostridium) difficile is a spore-forming, anaerobic, Gram-positive bacillus responsible for antibiotic-associated diarrhea in humans (BURKE \& LAMONT, 2014). In equines, $C$. difficile was first recognized as a pathogen more than 30 years ago (JONES, 1989). Despite its known importance as a major cause of diarrhea in colitis in foals and adult horses, the epidemiology of CDI in equine is still largely unknown (RODRIGUEZ et al., 2016). In fact, a previous study showed that veterinarians' lack of awareness of CDI makes it difficult to recognize the disease, commonly leading to unsuccessful treatment (SILVA et al., 2013). In addition to its role as an equine enteropathogen, there is some evidence of cross-species transmission of $C$. difficile, leading to the hypothesis that $C$. difficile infection (CDI) is a zoonotic disease (WEESE, 2020). 
Therefore, this study described six cases of equine CDI that occurred between 2014 and 2019 in Minas Gerais, Brazil. In this study, all obtained isolates were fully characterized to provide insights regarding the clinical and microbiological characteristics of CDI in horses and foals.

Six cases of CDI in equine that occurred between 2014 and 2019 (Table 1) were included in this study. Fecal samples of these animals were collected directly from the rectum in sterile containers and processed no later than $24 \mathrm{~h}$. The present study was approved by the institutional ethics committee of Universidade Federal de Minas Gerais (CEUAUFMG), protocol 013/2014.

For diagnosis of CDI, all fecal samples were submitted to $\mathrm{A} / \mathrm{B}$ toxins detection with a commercial ELISA test $(C$. difficile Tox A/B II Techlab Inc., USA). To isolate $C$. difficile, equal volumes of stool samples and $96 \%$ ethanol $(\mathrm{v} / \mathrm{v})$ were mixed and incubated for 30 minutes at room temperature. Thereafter, $20 \mu \mathrm{L}$ aliquots were inoculated on plates containing cycloserine-cefoxitin-fructose agar, supplemented with $7 \%$ horse blood and $0.1 \%$ sodium taurocholate (Sigma-Aldrich Co., USA). Following anaerobic incubation at $37{ }^{\circ} \mathrm{C}$ for 72 hours, all colonies with suggestive morphology (flat, irregular, and with ground-glass appearance) were subjected to a previously described multiplex-PCR for a housekeeping gene (tpi), the toxin A gene (tcdA), the toxin B gene $(t c d B)$, and a binary toxin gene $(c d t B)$ (SILVA et al., 2011). C. difficile isolates were PCR ribotyped and subjected to multilocus sequence typing as previously described (GRIFFITHS et al., 2010; JANEZIC \& RUPNIK, 2010). The antimicrobial susceptibility of the isolated strains $(n=6)$ against metronidazole, vancomycin, clindamycin and moxifloxacin were determined by the gradient test with the E-test method (Biomeriuex, Belgium) and the obtained values were interpreted according the CLSI (2017) and EUCAST (2019) guidelines.

All stool samples were also subjected to differential tests for the diagnosis of the most common enteropathogens in horses. For detection of Salmonella spp., stool samples were inoculated into Rappaport broth (Oxoid, USA) and plated onto Hektoen and MacConkey agar (Oxoid, USA) following incubation at $37{ }^{\circ} \mathrm{C}$ for $24 \mathrm{~h}$. Suggestive colonies were identified by PCR (KWANG et al., 1996) and serotyped at the Brazilian National Reference Laboratory of Enterobacteria of Oswaldo Cruz Foundation (FIOCRUZ) (GRIMONT \& WEILL, 2007). Samples were also plated on MacConkey agar (Oxoid, USA) for Escherichia coli isolation and up to three lactose-fermenting colonies were subjected to a PCR for the detection of specific virulent genes of $E$. coli pathovars (RAMOS et al.,

Table 1 - Clinical and epidemiological aspects, ribotyping (RT) and multilocus sequence typing (MLST) of Clostridioides difficile isolated from six equines with confirmed CDI. Brazil, 2014-2019.

\begin{tabular}{|c|c|c|c|c|c|c|c|c|}
\hline \multirow[t]{2}{*}{ Case } & \multirow[t]{2}{*}{ Age } & \multirow[t]{2}{*}{ Year } & \multirow{2}{*}{$\begin{array}{l}\text { First reason for } \\
\text { antimicrobial } \\
\text { therapy }\end{array}$} & \multirow[t]{2}{*}{$\begin{array}{l}\text { Nosocomial } \\
\text { infection }\end{array}$} & \multicolumn{3}{|c|}{ Clostridioides difficile diagnostic and characterization } & \multirow{2}{*}{$\begin{array}{c}\text { Other } \\
\text { enteropath } \\
\text { ogens }\end{array}$} \\
\hline & & & & & $\mathrm{A} / \mathrm{B}$ toxins $^{1}$ & Isolated strains $^{2}$ & $\begin{array}{l}\text { Antimicrobial } \\
\text { resistance }^{3}\end{array}$ & \\
\hline 1 & 13 years & 2014 & $\begin{array}{l}\text { Habronema } \\
\text { spp. infection }\end{array}$ & Yes & Positive & $\begin{array}{c}\mathrm{A}^{+} \mathrm{B}^{+} \mathrm{CDT}^{-} \\
\mathrm{RT} 014 / 020 / \mathrm{ST} 2\end{array}$ & - & - \\
\hline 2 & $\begin{array}{c}2 \\
\text { months }\end{array}$ & 2014 & Pasty diarrhea & No & Positive & $\begin{array}{c}\mathrm{A}^{+} \mathrm{B}^{+} \mathrm{CDT}^{+} \\
\mathrm{RT} 126 / \mathrm{ST} 11\end{array}$ & - & - \\
\hline 3 & $\begin{array}{c}7 \\
\text { months }\end{array}$ & 2015 & Joint infection & Yes & Positive & $\begin{array}{c}\mathrm{A}^{+} \mathrm{B}^{+} \mathrm{CDT}^{+} \\
\mathrm{RT} 078 / \mathrm{ST} 11\end{array}$ & CLIN & - \\
\hline 4 & 11 days & 2018 & $\begin{array}{c}\text { Surgery for } \\
\text { patent urachus }\end{array}$ & Yes & Positive & $\begin{array}{c}\mathrm{A}^{+} \mathrm{B}^{+} \mathrm{CDT}^{+} \\
\mathrm{RT} 126 / \mathrm{ST} 11\end{array}$ & MOX & $\begin{array}{c}S . \\
\text { Heidelberg }\end{array}$ \\
\hline 5 & $\begin{array}{c}3 \\
\text { months }\end{array}$ & 2018 & $\begin{array}{l}\text { Rhodococcus } \\
\text { equi infection }\end{array}$ & No & Positive & $\begin{array}{l}\mathrm{A}^{+} \mathrm{B}^{+} \mathrm{CDT}^{+} \\
\mathrm{RT} 126 / \mathrm{ST} 11\end{array}$ & MOX & $S$. Infantis \\
\hline 6 & $\begin{array}{c}2 \\
\text { months }\end{array}$ & 2019 & $\begin{array}{l}\text { Profuse } \\
\text { diarrhea }\end{array}$ & No & Positive & $\begin{array}{c}\mathrm{A}^{+} \mathrm{B}^{+} \mathrm{CDT}^{+} \\
\mathrm{RT} 126 / \mathrm{ST} 11\end{array}$ & CLIN, MOX & $S$. Infantis \\
\hline
\end{tabular}

${ }^{1}$ C. difficile Tox A/B II - Techlab Inc., Blacksburg, VA, USA; ${ }^{2}$ Ribotyping (RT), multilocus sequence typing (MLST); ${ }^{3}$ All strains were evaluated for resistance against metronidazole (MTZ), vancomycin (VAN), moxifloxacin (MOX) and clindamycin (CLI). 
2019). For C. perfringens isolation, Shahadi Ferguson Perfringens (SFP) agar (Difco, USA) were used and isolated colonies were genotyped as previously reported (MEHDIZADEH et al., 2015; VIEIRA et al., 2008). The presence of rotavirus and coronavirus was evaluated by commercial lateral flow tests according to the manufacturer's recommendation (Ecodiagnostica, Brazil). Fecal samples from animals 2 and 3 were also subjected to Lawsonia intracellularis detection by PCR (JONES et al., 1993) and oocyst detection by the flotation method (HOFFMANN, 1987).

In case 1 , an adult horse (13 years old) was admitted to the Veterinary Hospital of the Federal University of Minas Gerais (VH-UFMG) for treatment of a habronemiasis complicated by a possible secondary bacterial infection diagnosed clinically. Four days after receiving a single dose of benzylpenicillin and dihydrostreptomycin, the animal developed acute profuse diarrhea, and a stool sample was collected. The horse was positive for $\mathrm{A} / \mathrm{B}$ toxins and a toxigenic $C$. difficile strains was isolated. No other enteropathogens were detected. The animal was treated with metronidazole and it fully recovered after approximately four days.

In case 2, a 2-month-old female horse was examined on a farm by a veterinarian. The animal had a history of a two-day episode of pasty diarrhea; until that time, no antibiotics had been administered. During the clinical examination, the animal was active, without signs of dehydration, and with normal corporal temperature. A stool sample was collected, and the clinician prescribed florfenicol. The stool samples were negative for all enteropathogens tested, including $C$. difficile and its toxins. Four days after initiating antibiotic therapy, the animal showed a marked worsening of clinical status. During the clinician's second visit (five days after the onset of the antibiotic treatment), the animal was dehydrated with a profuse green watery diarrhea and a marked presence of gas in the intestines. After clinical examination, a new stool sample was collected and once again subjected to the differential diagnosis of enteropathogens. The animal was treated with fluid therapy, enrofloxacin, ceftiofur, and flunixin meglumine. The feces collected were positive for toxigenic $C$. difficile and $\mathrm{A} / \mathrm{B}$ toxins. The animal was then treated with metronidazole and it fully recovered following the administration.

In the third case, a 7-month-old male foal was admitted to the VH-UFMG for the management of a joint infection (septic arthritis). The animal received florfenicol and developed a profuse green diarrhea three to four days after the initiation of this treatment. Antibiotic therapy was discontinued, and a stool sample was collected. CDI was confirmed by the detection of $\mathrm{A} / \mathrm{B}$ toxins and isolation of toxigenic C. difficile; no other enteropathogens were detected. The diarrhea persisted after two days; thus; the animal was treated with metronidazole. On the fourth day of this treatment, the fecal consistency was found to be normal. Consequently, a combination of florfenicol and metronidazole was prescribed in order to treat the joint infection. The animal did not develop a new episode of diarrhea during this treatment.

In the fourth case, an 11-day-old male foal was subjected to surgery for patent urachus in the VH-UFMG. After the procedure, the animal received ceftiofur and gentamycin to prevent secondary bacterial infection. The foal developed a profuse green diarrhea two days after the onset of this treatment, and a stool sample was collected for differential diagnosis of the main enteropathogens. CDI was confirmed in this animal, but $S$. Heidelberg was also isolated. Despite this, only metronidazole was prescribed. The fecal consistency became pasty after three days and returned to normal after five days.

In case 5, a 3-month-old foal with a history of respiratory distress was examined on a farm by a veterinarian. During the clinical examination, the animal was dyspneic, with fever, cough, and abnormal breath sounds in the lungs. Rhodococcus equi infection was confirmed by isolation from a nasal swab and azithromycin and rifampicin were prescribed for a 20-day-therapy. Fifteen days after the initiation of the treatment, the animal developed profuse diarrhea with a gelatinous consistency. A/B toxins and toxigenic $C$. difficile were detected in the stool sample collected. $S$. Infantis was also isolated. As the treatment for pneumonia could not be discontinued at that time, the foal was maintained on azithromycin, and metronidazole was added. When the respiratory condition of the foal improved significantly after five days, azithromycin was discontinued. Conversely, the animal was still diarrheic at that time, and hence the treatment with metronidazole was maintained. The diarrhea only resolved completely seven days after the administration of treatment with metronidazole alone. Another stool sample was collected at this time and Salmonella Infantis was again isolated; A/B toxins were not detected, and $C$. difficile was not isolated.

In case 6, a 2-month-old male diarrheic foal was treated on a farm with ceftiofur due to a clinical suspicion of salmonellosis. A stool sample was collected on the second day of the onset of diarrhea; CDI was confirmed, and $S$. Infantis was isolated. Due to the detection of these two enteropathogens, 
the clinician decided to include metronidazole in the ongoing treatment (fluid therapy and ceftiofur). Four days after this prescription, the animal was still diarrheic, and a new stool sample was collected. Again, the animal was positive for Salmonella spp. and $\mathrm{A} / \mathrm{B}$ toxins, and toxigenic $C$. difficile were also detected. The clinician then decided to discontinue ceftiofur and the animal completely recovered five days after metronidazole monotherapy.

To the best of our knowledge, there are few studies that focus on the epidemiology and clinical characteristics of CDI in equine to date (DIAB et al., 2013). In the current report, we presented six successfully treated cases of CDI, including the full characterization of the isolates, which can add to the currently knowledge of the disease in horses and foals. In most of the cases included (five out of six), the onset of diarrhea was preceded by antimicrobial therapy. Disruption of the gut microbiota by previous antibiotic therapy is a known risk factor for CDI in humans and animals, including equine (DIAB et al., 2013; RODRIGUEZ et al., 2016; KACHRIMANIDOU et al., 2019). Interestingly, except for azithromycin, all antimicrobials prescribed prior to the development of CDI in the animals studied are listed as the most common compounds associated with CDI in horses, including erythromycin, trimethoprim/sulfonamides, $\beta$-lactam antimicrobials (cephalosporins and penicillin), clindamycin, rifampicin, and gentamicin (DIAB et al., 2013; KACHRIMANIDOU et al., 2019; NIWA et al., 2013). Nevertheless, it should be remembered that theoretically any antimicrobial can cause CDI (WEESE et al., 2006).

In case 2 , even though the animal was clinically in a good condition and showed mild symptoms, the veterinarian prescribed antimicrobial therapy, an approach not recommended by the current literature (WEESE et al., 2007; SVF, 2013). In addition, no enteropathogens were detected in a stool sample collected at the onset of diarrhea, confirming that antimicrobial therapy was hardly necessary in this animal. Later, the animal had a marked worsening of the clinical signs, with profuse diarrhea, and hence CDI was confirmed. This particular case shows how empiric use of antimicrobial agents in foals should be avoided due to the risk of inducing CDI, as previously reported (WEESE et al., 2007).

It is worth noting that three of these five animals (cases 1, 3, and 4) developed the disease during hospitalization which were then classified as nosocomial CDI. Hospitalization is clearly a predisposing factor for CDI in humans (BURKE \& LAMONT, 2014) and; although, seldom studied in animals, it has been recognized in horses (DIAB et al., 2013). In fact, simple hospitalization is known to be responsible for increasing the fecal shedding of $C$. difficile in horses (KECEROVA et al., 2019) and Salmonella spp. (CUMMINGS et al., 2016). Interestingly, antimicrobial administration and surgery were also shown to be risk factors for salmonellosis in hospitalized horses (CUMMINGS et al., 2016; ERNST et al., 2004), suggesting a possible co-infection in case 4.

In only one foal (case 6), diarrhea occurred without previous antimicrobial therapy or any other recognizable risk factor, which is known to occur sporadically (DIAB et al., 2013; NIWA et al., 2013; SILVA et al., 2013; WEESE et al., 2006). The possible coinfection with Salmonella spp., as seen in cases 4,5 and 6 , are also challenging due to the differences in the compounds used to treat these diseases. Antimicrobial therapy for CDI in equines is based on metronidazole, which is not effective at treating salmonellosis (CUMMINGS et al., 2016; SVF, 2013). Thus, a combination of antimicrobials could be necessary in these cases. In case 4 , the clinician decided to prescribe only metronidazole, believing that diarrhea-which started a few days after antimicrobial prescription-was solely due to CDI. Moreover, the fast recovery of the animal after metronidazole therapy may also suggested that Salmonella spp. was present only as part of the microbiota of the animal, a known possibility (UZAL \& DIAB, 2015).

In contrast to case 4, the foal from case 6 was treated simultaneously with ceftiofur and metronidazole due to the detection of Salmonella spp. and $C$. difficile. Interestingly, the animal only fully recovered after discontinuation of the beta-lactam antimicrobial, probably because of the difficulty imposed by this compound-used here to treat salmonellosis - in the microbiota recovery (LI et al., 2017). Similarly, in case 5, due to coinfection with $R$. equi, S. Infantis, and C. difficile, azithromycin and metronidazole were used together. Diarrhea was only resolved after the use of metronidazole monotherapy, suggesting that the action of azithromycin also impaired the microbiota recovery, thereby facilitating the maintenance of CDI (KHAN et al., 2016; LI et al., 2017). These findings should inform clinicians about the difficulties and outcomes expected when prescribing metronidazole with other antimicrobials to treat coinfections.

It is important to note that all animals were treated with metronidazole and recovered until seven days after treatment with this drug. Although, CDI 
is a life-threatening disease in equine, most animals recover well if diagnosed and promptly treated with metronidazole (SILVA et al., 2013; WEESE et al., 2006). This result also corroborated the results of antimicrobial susceptibility of the $C$. difficile isolates; all isolates were fully susceptible to metronidazole. Although, already described in humans and in some animals, including equines, $C$. difficile strains resistant to metronidazole can be considered rare (ANDRÉSLASHERAS et al., 2018; CHAHINE, 2018; JANG et al., 1997; KECEROVA et al., 2019).

Three strains were resistant to moxifloxacin and two were resistant to clindamycin; antimicrobials are known to increase the risk factors for CDI development in humans (BANDELJ et al., 2017; PIRŠ et al., 2013). Recently, KECEROVA et al. (2019) also reported resistance to clindamycin in $C$. difficile isolates from Czech horses. However, in contrast with this research, none of the 16 isolates tested were resistant to moxifloxacin. These differences reinforce the need for studies on antimicrobial resistance patterns of $C$. difficile isolates from animals due to their relevance to human health.

Several studies have suggested a possible transmission of $C$. difficile between animals and humans due to the high genetic similarity between isolates (RODRIGUEZ et al., 2016). In the present study, all $C$. difficile strains were from ribotypes (RT) and sequence types (ST) known to cause infections in humans worldwide (DINIZ et al., 2019; OFORI et al., 2018). Of note, five out of the six isolates were classified as RT078 or RT126, which has been linked to the increasing occurrence of community-acquired CDI in humans (OFORI et al., 2018; WARRINER et al., 2017), reinforcing the concern of animals as a possible source of toxigenic $C$. difficile strains.

The present study reported six cases of equine CDI. Most cases were associated with antimicrobial therapy, partly in hospitalized animals, and some spontaneously communityacquired infections were also seen. The isolated $C$. difficile strains showed resistance to some routinely prescribed antimicrobials and were from RT and ST typically associated with CDI in humans, reinforcing the need to a "One Health" approach to deal with $C$. difficile (KNIGHT \& RILEY, 2019).

\section{ACKNOWLEDGMENTS}

This research was supported by funds from Coordenação de Aperfeiçoamento de Pessoal de Nível Superior (Prêmio CAPES 2015 - 0774/2017), Conselho Nacional de Desenvolvimento Científico e Tecnológico (CNPq - 406402/20183), Fundação de Amparo à Pesquisa do Estado de Minas Gerais (FAPEMIG - APQ-00524-17).

\section{BIOETHICS AND BIOSSECURITY COMMITTEE APPROVAL}

All animal procedures in this study were approved by the institutional ethics committee of Universidade Federal de Minas Gerais (CEUA-UFMG), protocol 013/2014.

\section{DECLARATION OF CONFLICT OF} INTEREST

The authors declare no conflict of interest. The founding sponsors had no role in the design of the study; in the collection, analyses, or interpretation of data; in the writing of the manuscript, and in the decision to publish the results.

\section{AUTHORS' CONTRIBUTIONS}

All authors contributed to the study conception. Material preparation and data collection were performed by Diogo Cruz, Carolina Ramos, Carlos Oliveira Júnior, Isabella Winter and Jorge Lima. Analysis were performed by Armando Carvalho and Francisco Lobato. The first draft of the manuscript was written by Amanda Diniz and Rodrigo Silva. All authors read and approved the final manuscript.

\section{REFERENCES}

ANDRÉS-LASHERAS, S. et al. Preliminary studies on isolates of Clostridium difficile from dogs and exotic pets. BMC Veterinary Research, v.14, n.1, p.77, 2018. Available from: <https://doi. org/10.1186/s12917-018-1402-7>. Accessed: Dec. 16, 2019. doi: 10.1186/s12917-018-1402-7.

BANDELJ, P. et al. Antimicrobial Susceptibility Patterns of Clostridium difficile Isolates from Family Dairy Farms. Zoonoses and public health, v.64, n.3, p.213-221, 2017. Available from: $<$ https://doi.org/10.1111/zph.12299>. Accessed: Jun. 20, 2020. doi: $10.1111 /$ zph.12299.

BURKE, K. E.; LAMONT, J. T. Clostridium difficile infection: a worldwide disease. Gut and liver, v.8, n.1, p.1-6, 2014. Available from: $<$ https://doi.org/10.5009/gnl.2014.8.1.1>. Accessed: Jun. 22, 2020. doi: $10.5009 / \mathrm{gnl} .2014 .8 .1 .1$.

CHAHINE, E. B. The Rise and Fall of Metronidazole for Clostridium difficile Infection. The Annals of pharmacotherapy, United States, v.52, n.6, p.600-602, 2018. Available from: <https:// doi.org/10.1177/1060028018757446>. Accessed: Jun. 20, 2020. doi: $10.1177 / 1060028018757446$.

CLSI. M100 Performance Standards for Antimicrobial Susceptibility Testing. 2017. Available from: <http://www. emeraldinsight.com/doi/10.1108/08876049410065598>. Accessed: Jun. 20, 2020.

CUMMINGS, K. J. et al. Antimicrobial resistance trends among Salmonella isolates obtained from horses in the northeastern United States (2001-2013). Am. Jour. Vet. Research, v.77, n.5, p.505-13, 2016. Available from: <https://doi.org/10.1089/fpd.2013.1605>. Accessed: Jun. 17, 2020. doi: 10.1089/fpd.2013.1605.

DIAB, S. S. et al. Clostridium difficile infection in horses: A review. Veterinary Microbiology, v.167, n.1-2, p.42-49, 2013. Available 
from: <https://doi.org/10.1016/j.vetmic.2013.03.032>. Accessed: Jul. 03, 2020. doi: 10.1016/j.vetmic.2013.03.032.

DINIZ, A. N. et al. Molecular epidemiology of Clostridioides (previously Clostridium) difficile isolates from a university hospital in Minas Gerais, Brazil. Anaerobe, v.56, p.34-39, 2019. Available from: <https://doi.org/https://doi.org/10.1016/j. anaerobe.2019.01.010>. Accessed: Jun. 20, 2020. doi: 10.1016/j anaerobe.2019.01.010.

ERNST, N. S. et al. Risk factors associated with fecal Salmonella shedding among hospitalized horses with signs of gastrointestinal tract disease. Journal of the American Veterinary Medical Association, United States, v.225, n.2, p.275-281, 2004. Available from: $<$ https:// doi.org/10.2460/javma.2004.225.275>. Accessed: Jun. 20, 2020.

EUCAST. The European Committee on Antimicrobial Susceptibility Testing. Breakpoint tables for interpretation of MICs and zone diameters. Version 9.0.

GRIFFITHS, D. et al. Multilocus Sequence Typing of Clostridium difficile. Journal of Clinical Microbiology, v.48, n.3, p.770, 2010. Available from: <https://doi.org/10.1128/JCM.01796-09>. Accessed: Jun. 17 2020. doi: 10.1128/JCM.01796-09.

GRIMONT, P. A; D.; WEILL, F.-X. Antigenic formulae of the Salmonella serovars. WHO Collaborating Centre for Reference and Research on Salmonella. 2007. Available from: <https://www. pasteur.fr/sites/default/files/veng_0.pdf $>$. Accessed: Jan. 2, 2021.

HOFFMANN, R. P. Diagnostico de Parasitismo Veterinario. Porto Alegre: 1987.

JANEZIC, S.; RUPNIK, M. Molecular typing methods for Clostridium difficile: pulsed-field gel electrophoresis and PCR ribotyping. Methods in molecular biology, v. 646, p. 55-65, 2010. Available from: <https://doi.org/10.1007/978-1-60327-365-7 4>. Accessed: Jun. 23, 2020. doi: 10.1007/978-1-60327-365-7_4.

JANG, S. S. et al. Antimicrobial susceptibilities of equine isolates of Clostridium difficile and molecular characterization of metronidazole-resistant strains. Clinical infectious diseases, United States, v.25 Suppl 2, p.S266-7, 1997. Available from: $<$ https://doi.org/10.1086/516235>. Accessed: Jun. 23, 2020. doi: $10.1086 / 516235$.

JONES, G. F. et al. Enhanced detection of intracellular organism of swine proliferative enteritis, ileal symbiont intracellularis, in feces by polymerase chain reaction. Journal of clinical microbiology, United States, v.31, n.10, p.2611-2615, 1993. Available from: <https://www.ncbi.nlm.nih.gov/pmc/articles/PMC265945/>. Accessed: Jan. 2, 2021

JONES, R. L. Diagnostic procedures for isolation and characterization of Clostridium difficile associated with enterocolitis in foals. Journal of veterinary diagnostic investigation, United States, v.1, n.1, p.84-86, 1989. Available from: <https://doi.org/ 10.1177/104063878900100125>. Accessed: Jun. 20, 2020. doi: $10.1177 / 104063878900100125$.

KACHRIMANIDOU, M. et al. Clostridioides (Clostridium) difficile in Food-Producing Animals, Horses and Household Pets: A Comprehensive Review. Microorganisms, v.7, n.12, 2019. Available from: <https://doi.org/10.3390/ microorganisms7120667>. Accessed: Jun. 20, 2020. doi: 10.3390/ microorganisms 7120667 .
KECEROVA, Z. et al. Clostridium difficile isolates derived from Czech horses are resistant to enrofloxacin; cluster to clades 1 and 5 and ribotype 033 predominates. Anaerobe, v.56, p.17-21, 2019. Available from: <https://doi.org/https://doi.org/10.1016/j. anaerobe.2019.01.005> . Accessed: Jun. 20, 2020. doi: 10.1016/j. anaerobe.2019.01.005

KHAN, I. et al. Metagenomic Analysis of Antibiotic-Induced Changes in Gut Microbiota in a Pregnant Rat Model. Frontiers in pharmacology, v.7, p.104, 2016. Available from: <https://doi. org/10.3389/fphar.2016.00104>. Accessed: Jun. 20, 2020. doi: 10.3389/fphar.2016.00104.

KNIGHT, D. R.; RILEY, T. V. Genomic Delineation of Zoonotic Origins of Clostridium difficile. Frontiers in public health, v.7, p.164, 2019. Available from: <https://doi.org/10.3389/fpubh.2019.00164>. Accessed: Jun. 20, 2020. doi: 10.3389/fpubh.2019.00164.

KWANG, J. et al. Use of the polymerase chain reaction for Salmonella detection. Letters in applied microbiology, v.22, n.1, p.46-51, 1996. Available from: < https://core.ac.uk/download/ pdf/188089505.pdf $>$. Accessed: Jun. 20, 2020.

LI, R. et al. Effects of oral florfenicol and azithromycin on gut microbiota and adipogenesis in mice. PloS one, v.12, n.7, p.e0181690, 2017. Available from: <https://doi.org/10.1371/ journal.pone.0181690>. Accessed: Jun. 20, 2020. doi: 10.1371/ journal.pone. 0181690

MEHDIZADEH, I. G. et al. A novel pore-forming toxin in type A Clostridium perfringens is associated with both fatal canine hemorrhagic gastroenteritis and fatal foal necrotizing enterocolitis. PLoS ONE, v.10, n.4, p.1-27, 2015. Available from: <https://doi. org/10.1371/journal.pone.0122684>. Accessed: Jun. 20, 2020. doi: 10.1371/journal.pone.0122684.

NIWA, H. et al. Postoperative Clostridium difficile infection with PCR ribotype 078 strain identified at necropsy in five Thoroughbred racehorses. The Veterinary record, England, v.173, n.24, p.607, 2013. Available from: <https://doi.org/10.1136/ vr.101960>. Accessed: Jun. 20, 2020. doi: 10.1136/vr.101960.

OFORI, E. et al. Community-acquired Clostridium difficile: epidemiology, ribotype, risk factors, hospital and intensive care unit outcomes, and current and emerging therapies. The Journal of hospital infection, England, v.99, n.4, p.436-442, 2018. Available from: $\quad<$ https://doi.org/10.1016/j.jhin.2018.01.015>. Accessed: Jun. 20, 2020. doi: 10.1016/j.jhin.2018.01.015.

PIRŠ, T. et al. Antimicrobial susceptibility of animal and human isolates of Clostridium difficile by broth microdilution. Journal of Medical Microbiology, v.62, n.9, p.1478-1485, 2013. Available from: <https://pubmed.ncbi.nlm.nih.gov/23861298/>. Accessed: Jun. 20, 2020. doi: 10.1099/jmm.0.058875-0.

RAMOS, C.P. etal. Identification and characterization of Escherichia coli, Salmonella spp., Clostridium perfringens, and C. difficile isolates from reptiles in brazil. BioMed Research International, v.2019, 2019. Available from: <https://doi.org/10.1155/2019/9530732>. Accessed: Jun. 20, 2020. doi: 10.1155/2019/9530732.

RODRIGUEZ, C. et al. Clostridium difficile in Food and Animals: A Comprehensive Review. Advances in Microbiology, Infectious Diseases and Public Health, v.932, p.65-92, 2016. Available from: < https://doi.org/10.1007/5584_2016_27>. Accessed: Jun. 20, 2020. doi: 10.1007/5584 201627. 
SILVA, R. O. S. et al. Detection of enterotoxin A and cytotoxin B, and isolation of Clostridium difficile in piglets in Minas Gerais, Brazil. Ciencia Rural, v.41, n.8, p.1430-1435, 2011. Available from: $\quad<$ https://doi.org/10.1590/S0103-84782011005000100> Accessed: Jun. 20, 2020. doi: 10.1590/S0103-84782011005000100.

SILVA, R. O. S. et al. Detection of A/B toxin and isolation of Clostridium difficile and Clostridium perfringens from foals. Equine Veterinary Journal, v.45, n.6, p.671-675, 2013. Available from: <https://doi.org/10.1111/evj.12046>. Accessed: Jun. 22, 2020. doi: 10.1111/evj.12046.

SVF. The Swedish Veterinary Association's Guidelines for the Clinical Use of Antibiotics in the Treatment of Horses. Sweden: 2013. Accessed: Jun. 25, 2020.

UZAL, F. A.; DIAB, S. S. Gastritis, Enteritis, and Colitis in Horses. The Veterinary clinics of North America Equine practice, v.31, n.2, p.337-358, 2015. Available from: <https://doi.org/10.1016/j. cveq.2015.04.006>. Accessed: Jun. 21, 2020. doi: 10.1016/j. cveq.2015.04.006

VIEIRA, A. A. S. et al. Genotipagem de Clostridium perfringens isolados de leitões diarréicos. Arquivos do Instituto Biológico, v.75, n.4, p.513-516, 2008. Available from: <http://www. biologico.agricultura.sp.gov.br/uploads/docs/arq/v75_4/vieira. pdf>. Accessed: Jun. 20, 2020.

WARRINER, K. et al. Dissemination of Clostridium difficile in food and the environment: Significant sources of C. difficile communityacquired infection? Journal of applied microbiology, England, v.122, n.3, p.542-553, 2017. Available from: <https://doi.org/10.1111/ jam.13338>. Accessed: Jun. 20, 2020. doi: 10.1111/jam.13338.

WEESE, J. S. et al. Guidelines for Antimicrobial Use in Horses. In: GUARDABASSI, L.; LARS BOGO JENSEN; HILDE KRUSE (org.). Guide to Antimicrobial Use in Animals. 1. ed.: Wiley Blackwell, 2007. p.161-182.

WEESE, J. S. Clostridium (Clostridioides) difficile in animals Journal of Veterinary Diagnostic Investigation, v.32, n.2, 2020. Available from: <https://doi.org/10.1177/1040638719899081>. Accessed: Jun. 20, 2020. doi: 10.1177/1040638719899081.

WEESE, J. S. et al. Clostridium difficile associated diarrhoea in horses within the community: predictors, clinical presentation and outcome. Equine veterinary journal, United States, v.38, n.2, p.185-188, 2006. Available from: <https://doi.org/1 0.2746/042516406776563369>. Accessed: Jun. 20, 2020. doi: $10.2746 / 042516406776563369$. 